\title{
The New Montreal Protocol: A Small Step for the Protection of the Ozone Layer, a Big Step for International Law and Rela- tions
}

\author{
By Hermann Ott
}

\section{Introduction}

From June 27 to 29, 1990, the parties to the Montreal Protocol on Substances that Deplete the Ozone Layer met in London ${ }^{1}$ to negotiate and adopt an amendment which is remarkable in many ways 2 , and may very well open "a new chapter in international relations 3 .

The parties to the Montreal Protocol did not only agree to phase out completely the production and consumption of a whole range of chemical substances which are known to destroy the ozone layer. 4 The parties also reached an unprecedented agreement on a financial mechanism with as of yet unforseeable consequences for North-South relations, for the international economic order and for international law. This financial mechanism will be funded by the industrialized states and is designed to enable developing countries to restructure their industries in order to avoid using ozone-depleting substances. Thus the conference may have set quite an important precedent in the fight against global environmental deterioration and may prove to be a step towards a genuinely sustainable development.

I shall first give a brief account of the scientific evidence necessary to comprehend the scope of the problem and some examples of the national and international legislative reactions. Secondly, the decisions taken at the London Meeting and the changes to the Montreal Protocol shall be dealt with. Finally, I shall comment on the results and draw some conclusions with regard to their possible medium and long-term implications.

1 See the Report of the Second Meeting of the Parties to the Montreal Protocol on Substances that Deplete the Ozone Layer, UNEP/Ozl. Pro. 2/3, 29 June 1990; the material of the Meeting and the changes to the Protocol have not been published yet, any references will therefore be made to this report.

2 The author is tempted to use the term "historical", which has been used for the original Protocol already, cf. W. Lang, Diplomatie zwischen Ökonomie und Ökologie, Europa-Archiv 1988, 105, 109.

3 UNEP's Executive Director Mostafa Tolba in his opening address.

4 Although a much tighter time-schedule for the phase-out would have been desirable and possible, for a discussion see infra. 


\section{The Threat to the Ozone Layer: Scientific Background}

Already in 1974, two scientists discovered, that chlorofluorocarbons (CFC's), extremely inert chemical substances, diffuse upward into the stratosphere, where they are broken down by ultraviolet radiation. 5 This process releases free chlorines which in turn react catalytically with ozone and split it up. These CFC's and other ozone-depleting substances like Halons and Methyl Chloroform are almost inextricably linked with modem consumer society, having found widespread use since their discovery in the 1930's as aerosol propellants, as a heat-transfer medium in refrigeration and air-conditioning, in the production of plastic foams, and as solvents in cleaning agents used in the electronic industry. Ozone $\left(\mathrm{O}_{3}\right)$ is an armospheric trace gas vital for life on earth, since it absorbs ultraviolet radiation at a wavelength (UV-B) that is harmful to human beings and ecosystems. 6 A reduction in ozone concentrations would most significantly result in an increase of the incidence of skin cancer. Recent research indicates that a one percent decrease in ozone would result in a two percent increase in UV-B and cause an increase of non-melanomas amounting to approximately four percent. 7 The Environmental Protection Agency (EPA) of the United States estimated that a continuing growth in the use of CFC's at a rate of 2.5 percent would result in an additional 150 million cases of skin cancer, leading to more than 3 million deaths in the US-popolation bom before 2075.8 Increased ultraviolet radiation is also known to affect the immune system, leading to a higher rate of infectious diseases and eye disorders. 9 Effects on ecosystems include a change in the genetic make-up of phytoplancton communities, killing early states of aquatic life with resulting negative effects of the food chain 10 and decreasing productivity of terrestrial plants. CFC's also possess a significant

5 Molina/Rowland, Stratospheric Sink for Chlorofluoromethanes: Chlorine Atom Catalyzed Destruction of Ozone, 249 Nature 810 (1974); this danger was, however, raised and made public even ten years earlier by scientist J. P. Lodge. He reported his findings to the chemical industry who conducted some research and the issue was forgotten again until Molina and Rowlands report, cf. S. M. Williams, A Historical Background on the Chlorofluorocarbon Ozone Depletion Theory and its Legal Implications, in: Flinterman/Kwiatkowska/Lammers, Transboundary Air Pollution. International Legal Aspects of the Cooperation of States (1986), 267, 269.

6 For a recent detailed description of ozone-depleting processes see Umweltbundesamt (Federal Environmental Agency), Responsibility Means Doing Without - How to Rescue the Ozone Layer, 1989 (hereinafter FEA 1989), originally published as Report 7/89 under the title: Verzicht aus Verantwortung - Maßnahmen zur Rettung der Ozonschicht, 1989; for more background information see Miller/Mintzer, The Sky is the Limit. Strategies for Protecting the Ozone Layer, World Resources Institute, Nov. 1986.

7 FEA 1989, note 6, p. 29; R. J. Engelmann, A look at some issues before an Ozone Convention, in: 8 Environmental Policy and Law (1982), 49.

8 EPA, Regulatory Impact Analysis: Protection of Stratospheric Ozone, ES-4 (1987), quoted by $P$. M. Morrisette, The Evolution of Policy Responses to Stratospheric Ozone Depletion, in: 29 Natural Resources Joumal (1989), 793, 797.

9 FEA 1989, note 6, p. 28.

10 Engelmann, note 7, p. 49; FEA 1989, note 6, p. 29. 
greenhouse potential, i.e. 1000 to 10000 times greater than that of carbon dioxide. ${ }^{11}$ Therefore, any action to control CFC's will also contribute to the prevention of a possible greenhouse-effect 12 , which might fundamentally change the conditions of human life on earth.

\section{National and International Legislative Reactions}

The reaction to these findings on the national and international level can be characterized as sudden alarm, followed by a period of relaxation which ended abruptly with the discovery of the ozone-hole over the Antarctic. 13 In a rather swift responses the United States banned the non-essential use of CFC's in aerosols. Their use as refrigerants was not limited14, however, an omission, which led to an increase in the production and consumption of CFC's in the 1980's. Some European states like Sweden, Norway and Denmark also prohibited the use of CFC's as propellants 15 , whereas the Netherlands required waming labels on spray cans and West Germany relied on voluntary 16 reduction-promises on the part of industry17. Due to the strong resistance of France and the United Kingdom 18 the reaction of the European Communities was even slower. 19 After merely stating in 1978 that the problem could no longer be ignored 20 , the Council adopted a decision in 1980, which stipulates a freeze of production capacities in a 30 percent reduction in the use of CFC's 21 . a move that just fixed the status quo 22 .

11 FEA 1989, note 6, p. 31.

12 This effect is characterized by a continued "heating-up" of the worlds atmosphere, caused by trace gases which allow short-wave solar radiation to pass through the atmosphere but reflect long-wave radiation emitted from the earth's surface, thereby warming up the lower atmosphere, cf. the report prepared for the Second World Climate Conference, Intergovemmental Panel on Climate Change, Overview and Conclusions (Draft), July 1990; cf. also Hans Oeschger in the Neue Zürcher Zeitung, Nr. 145, 30 June/1 July 1990, p. 23.

13 Cf. Morrisette, note 8; for a general study on policy responses to environmental threats cf. Hahn/ Richards, The Intemationalization of Environmental Regulation, 30 Harvard Intemational Law Review (1989), 421.

14 Morrisette, note 8, p. 806; Williams, note 5, p. 270 et seq.

15 Ibid.

16 Recently the West German Minister for the Environment, Klaus Töpfer, has expressed the inadequacy of voluntary restraints, see FEA 1989, note 6, Introduction p. III; the West German Bundestag unanimously called for regulation on this matter, see B-Tag Doc. No. 11/4133, reprinted ibid., Annex p. 43.

17 FEA 1989, note 6, p. 182 et seq.

18 Morrisette, note 8, p. 806.

19 For a good analysis see $M$. Jachtenfuchs, The European Communities and the Protection of the Ozone Layer, in: 28 Joumal of Common Market Studies (1990), p. 261.

20 Official Joumal of the European Communities (OJEC), L 133, 7 June, p. 1: Council Resolution of 30 May 1978.

21 OJEC, L 90, 3 April, p. 45: Council Decision 80/372 of 26 March 1980.

22 Jachtenfuchs, note 19, p. 263. 
Meanwhile, the threat posed to the ozone layer was played down by scientists ${ }^{23}$ and by a massive campaign of the chemical industry 24 . This led to a widespread conviction, that the decisions taken in the legal field might have been premature and that the ozone controversy might slip slowly and inevitably into history. 25 The discovery of a fall in ozone concentration levels over Antarctica between 40 and 90 percent brought about an abrupt change and a renewed sense of urgency. 26

On the international level the instigation and coordination of research was conducted by the World Meteorological Organization (WMO), the Organization for Economic Cooperation and Development (OECD) and, most prominently, the United Nations Environment Programme (UNEP)27. In March 1977 UNEP28 took up the issue by convening an international meeting on stratospheric ozone in Washington, which resulted in the World Plan of Action on the Ozone Layer. In May 1977 UNEP established the Co-ordination Committee on the Ozone Layer (CCOL), including representatives from national and international agencies as well as from non-governmental organizations. 29 Whereas this body was concerned with the assessment of research results and data on impacts, UNEP decided in May 1981 to establish an ad-hoc Working Group to draft a Global Framework Convention for the Protection of the Ozone Layer 30 . Four years of extensive negotiations led to the adoption of the Vienna Convention for the Protection of the Ozone Layer by 20 states and

23 "... frivolous ozone depletion theories ..." according to Prof. Scorer from Imperial College, London in 1975, cf. Williams, note 5, p. 271.

24 Like Du Pont, the worlds largest producer of CFC's, who issued a comment of more than 1.000 pages plus copies of 191 reports and articles, cf. Williams, note 5, p. 273.

25 Cf. e.g. Williams, note 5, p. 278; being confronted with such errors it is all the more important to stress the principle of precaution in the regulation of technology and development, see generally Hans Jonas, Das Prinzip Verantwortung, 1984; for a recent legal controversy on whether there exists a duty to protect future generations cf. the contributions of d'Amato, Brown-Weiss and Gündling, in: 84 American Joumal of Intemational Law (2990), pp. 190, 198, 207.

26 The so-called "ozone-hole", cf. Farmer/Gardiner/Shanklin, Large Loss of Total Ozone in Antarctica Reveal Seasonal CLOx/NOx Interaction, 315 nature (1985), p. 207; this hole was not reported by the NASA satellite- und computer-based research center, because its computers analysing the stream of data from space were programmed to throw out abnormal readings, thereby dilligently ditching the evidence of the formation of the hole, cf. The Independent on Sunday, 24 June 1990: "The last of the string and sealing-way boffins".

27 Morrisette, note 8, p. 807; for a good summary of UNEP's work on this issue cf. I. RunnelBulska, The Protection of the Ozone Layer Under the Global Framework Convention, in: Flintermann/Kwiatkowska/Lammers, note 5, p. 281 and $H$. Heimsoeth. The Protection of the Ozone Layer, 10 Environmental Policy and Law (1983), p. 34.

28 For a general assessment of UNEP's performance see $M$. A. Gray, The United Nations Environment Programme: An Assessment, 20 Envtl. L. (1990), p. 291 and P. H. Sand, Intemationales Umweltrecht im Umweltprogramm der Vereinten Nationen, Natur und Recht 5 (1985), p. 170.

29 Not any environmental NGO's, however, but the Chemical Manuf acturers Association.

30 Rummel-Bulska, note 27, p. 282; Morrisette, note 6, p. 808. 
the EEC. ${ }^{31}$ The Convention is designed as an "umbrella treaty" and does not stipulate concrete measures32: The parties to this Convention recognize their responsibility to prevent further deterioration of the ozone layer and stipulate scientific cooperation, the exchange of information and the coordination of legal and administrative countermeasures. Being only a "framework" for future action, the Convention does not specify detailed obligations. Such obligations are to be agreed on at a later stage in separate protocols according to its Article 8. The time to adopt such a protocol came only two years later, when the drastic loss of ozone over antarctic and arctic regions became known and when the end of the global economic recession had led to a rapid growth in the demand for CFC's. 33 Mainly due to continued pressure from the United States, the European States and Japan finally agreed on the Montreal Protocol on Substances that Deplete the Ozone Layer 34. This original Protocol (now amended) provided for a 50 percent reduction of some widely used CFC's compared to 1986 levels of production and consumption, and for a freeze on 1986 levels of three Halons 35 . Nevertheless, even at that time there was a general feeling that these measures were insufficient and scientists called for an 85 percent cut in the production and consumption of CFC's. 36 Only 5 months after the Protocol entered into force, on 1 January 1989, the parties themselves declared it inadequate on the occasion of their first meeting. 37 Apart from the commitment to phase out CFC's by the year 2000, the parties also stressed the need to develop appropriate funding mechanisms to enable developing countries to join the Protocol and to facilitate their access to scientific information, research results and training. One year later the parties met again in London to revise the Protocol.

31 UNEP/IG.53/5; reprinted in the Official Joumal of the European Communities (OJEC), L 297, p. 10, 31 Oct. 1988 and 14 Environmental Policy and Law (1985), p. 71; German text in BGBl. 1988 II, 901; for views on the conference and its results see $N$. Letalik, Vienna Convention for the Protection of the Ozone Layer, 1 Intemational Insights (1985), p. 88 and $P$. Sand, The Vienna Convention is adopted, 27 Environment (1985), p. 19.

32 Sand, note 31.

33 Morrisette, note 8, p. 809.

34 Reprinted in OJEC, L 297, p. 21, 31 Oct. 1988; German text in BGBl. 1988 II, 1014.

35 For a description see T. Bunge, International Agreements, in FEA 1989, note 6, p. 165; see also J. Brunnée, Acid Rain and Ozone Layer Depletion: International Law and Regulation, 1988; for further discussion see infra.

36 J. Farman, What hope forthe ozone layer now?, New Scientist, 12 November 1987.

37 See the Helsinki Declaration on the Protection of the Ozone Layer, Appendix I to the Report of the Parties to the Montreal Protocol on the Work of their First Meeting, UNEP/Ozl. Pro. 1/5, 6 May 1989. 


\section{Legal Status of the Decisions adopted in London}

The Ozone Layer Regime 38 by now constitutes a very complex system of rules, framed in a variety of legal forms which make it difficult to comprehend. It is for this reason the Meeting decided "to invite the Executive Director to prepare as soon as possible a Montreal Protocol Handbook, setting out the Protocol as adjusted, the Protocol as adjusted and amended, and the decisions of the parties that relate to its interpretation ..."39. This quotation already indicates the main legal forms: There is first of all the Amendment to the Protocol, adopted by the Meeting according to Art. 9 para. 4 of the Vienna Convention 1985. It contains the introduction of control measures for substances formerly uncovered, the establishment of a financial mechanism to facilitate the compliance of developing countries with the requirements of the Protocol, a new clause dealing with the transfer of technology to developing countries, and other substantial changes. 40 Secondly, there is the adjustment of control measures relating to substances which were already covered by the original Protocol, made by a simple decision of the parties on the basis of Art. 2 para. 9 (a) (ii) and Art. 11 para. 4 (b) of the Montreal Protocol itself.41 These provisions allow for a revision of the Protocol by a two-thirds majority of the parties without any ratification procedures.

The third type of decisions 42 was adopted by the Meeting according to other provisions of the Protocol.43 These decisions are not reflected in the text of the Montreal Protocol but are indispensible for its interpretation. Moreover, these decisions may be accompanied by appendices, either clarifying clauses of the decision or providing additional rules required for their functioning. $44 \mathrm{It}$ is the growing need for an independent regime with very detailed rules, representing very delicate compromises, that is reflected in this complex system. The approach taken by this article is to follow these formal distinctions and to structure according to the legal status of the decision in question. Therefore, it shall firstly deal with the adjustments to the Protocol, secondly with its Amendment and finally with the (ordinary) decisions adopted at the Meeting.

38 Cf. E. Klein, Intemational Regimes, in R. Bernhardt (ed.), Encyclopedia of Public Intemational Law (EPIL), Instalment 9 (1987), p. 202; for the Gennan political science cf. B. Kohler-Koch (ed.), Regime in den intemationalen Beziehungen, 1989.

39 Decisions II/, UNEP/Ozl. Pro. 2/3, p. 12.

40 Cf. Annex II, p. 25 of the Report, UNEP/Ozl. Pro. $2 / 3$.

41 Cf. Annex I to the Report, UNEP/Ozl. Pro. 2/, p. 22.

42 Which may be called "ordinary decisions".

43 Cf. the Report of the Meeting, UNEP/Ozl. Pro. 2/3,p. 11.

44 Cf. Annex IV to the Report, UNEP/Ozl. Pro. 2/, p. 42; for example, the Interim Financial Mechanism was established by decision of the parties and is accompanied by appendices containing inter alia the terms of reference of its Executive Committee. 


\section{The Results of the London Meeting}

\section{a) Adjustments to the Montreal Protocol}

The original Montreal Protocol of 1987 deals with only two groups of ozone-depleting substances, listed in Annex A of the Protocol: the CFC's F 11, F 12, F 113, F 114, F 115 in Group I and the Halons 1211, 1301 and 1402 in Group II.45 Considerable criticism has been raised against this limited range of chemicals, which excludes some substances with high ozone-depleting potentials. The rather soft handling of these dangerous substances met with even stronger objections 46: Due to political struggles in which the European Communities played a rather inglorious role 47 , the Protocol only calls for a 50 percent reduction in production and consumption of CFC's by 1999 and a freeze in the use of Halons by 1992. The inadequacy of these measures was evident from the beginning and the necessity to strengthen them became paramount after new research revealed the growing loss of ozone not only over Antarctica, but also arctic and equatorial regions. 48

Not surprisingly, however, the tightening of these measures was not a big issue in the Working Group and the Meeting of the parties. The brackets stayed in the draft text of the proposed Adjustment until the last day to become part of a larger political package deal.49 However, the reduction schedule for Halons had been agreed upon beforehand, requiring a 50 percent reduction of 1986 levels in production and consumption from 1995 onwards and a complete phase-out in the year 2000.50 The term "phase-out" has to be used with some caution though, because all control measures do allow for a maximum of $15 \%$ of the controlled substances to be produced even after the final phase-out date in order to satisfy the basic domestic needs of developing countries.

The last day of the Meeting then saw a rift between the Nordic Countries, the EC, Australia and Canada on the one hand, pressing for a phase-out as early as 1997/98 and an alliance of the US, Japan and the USSR aiming at a delayed phase-out in the year 2000.51 In the end,

45 See T. Bunge, note 35, p. 165 et seq.; Brunnée, note 35; Lang, note 3.

46 Greenpeace, The failure of the 1990 Montreal Protocol, 1990; cf. also Bunge, note 35, p. 171.

47 The EC was not prepared to accept a reduction and used this to increase its bargaining power in order to improve its political and legal status, cf. Jachtenfuchs, note 19; Lang, note 2, p. 106; W. Lang, Luft und Ozon - Schutzobjekte des Völkerrechts, Zeitschrift für ausländisches öffentliches Recht und Völkerrecht (ZaöRV) 46 (1985), p. 261, 271.

48 United Kingdom Stratospheric Ozone Review Group: Stratospheric Ozone 1990, London, HMSO; the growing threat was also underlined by oral evidence of Prof. Ivar Isaksen in plenary.

49 See the last draft: UNEP/Ozl. Pro. 2/L.3., 26 June 1990.

50 Cf. UNEP/Ozl. Pro. 2/L.3., 26 June 1990.

51 Because of high public expectations it was impossible to stay behind that goal, although some delegations would have liked to. 
the parties agreed on a phase-out in the year $2000^{52}$, a compromise that was reached by reconciling different economical, political and ecological interests, in which the latter played the smallest role. 53

The result is highly unsatisfactory from an environmental point of view and has been described as "past its 'use by' date today".54 Combined with a soft time-schedule 55 the amount of CFC's and other ozone destroying chemicals released into the atmosphere will still be six times higher than the amount produced in 198656 and reach almost half the amount ever released into the atmosphere 57 . The resistance of some states to stricter measures becomes rather incomprehensible bearing in mind that it takes 10 years for these substances to climb up into the stratosphere to start their destructive work 58 and that they have a life-time of up to 100 years 59 . A group of parties issued a declaration expressing their intention to phase-out all CFC's as soon as possible, but no later than 1997.60 They also pressed for a clause stipulationg a review of the situation in 1992 with the objective of accelerating the reduction schedule 61 .

Notwithstanding this it is most noteworthy that for the first time in history a group of states has agreed to live without a whole range of chemical substances. 62 This may prove to be only the beginning as other potentially destructive chemical substances are already on the waiting list.

52 Art. 2 A para. 5 of the new Protocol, UNEP/Ozl. Pro. 2/3, p. 23.

53 Forthe theoretical background of environmental agreements cf. Hahn/Richards, note 13, p. 421 et seq.; Morrisette, note 8.

54 The Independent, 30 June 1990.

5550 per cent reduction in 1995 and 85 per cent in 1997, see Art. 2 A paras. 3 and 4, UNEP/Ozl. Pro. 2/, pp. 22, 23.

56 Natural Defense Council press release, 24 June 1990.

5715.6 million tonnes of CFC 11 and 12 were produced between 1930 and 1986 (Economic Panel Report, UNEP 1989), whereas the reductions agreed upon will still allow an additional 8 million tons (Greenpeace estimate, note 46); this does not even take into account now and additional ozone depleting substances.

58 Engelmann, note 7, p. 51.

59 Morrisette, note 8, p. 796.

60 Statement of 29 June 1990 by Australia, Austria, Belgium, Canada, Denmark, West Germany, Finland, Liechtenstein, Netherlands, New Zealand, Norway, Sweden and Switzerland, UNEP/Ozl. Pro. 2/3, p. 20; some states like Belgium and West Germany are firmly committed to phase out these controlled substances by 1995 .

61 Art. 2 A para. 6, UNEP/Ozl. Pro. 2/3, p. 23.

62 Although it remains to be seen whether the parties will adopt a decision identifying essential uses for Halons which would allow them to continue production on a limited scale, cf. Art. 2 B (4), UNEP/Ozl. Pro. 2/3, p. 24. 


\section{b) Amendments to the Montreal Protocol}

The revision of the Montreal Protocol constitutes the core of the decisions adopted in London. The changes range from the inclusion of new ozone-depleting substances into a reduction schedule (Arts. $2 \mathrm{C}-2 \mathrm{E}$ ) to the establishment of a Financial Mechanism (Art. 10) and other provisions to ease the adherence of developing countries to the control measures of the Protocol (Art. 5).

\section{aa) Further Control Measures}

The London Amendment to the Montreal Protocol introduces new reduction schedules for "other fully halogenated CFC's" (Art. 2C), listed in Group I of the new Annex B, Carbontetrachloride (Art. 2 D), listed in Group II and Methylchloroform (Art. 2 E) listed in Group III of Annex B.63 Base year for the production and consumption of these substances will not be 1986 - as in the case of CFC's and Halons - but 1989, for the reason that several parties argued not to have available any data on 1986 levels. For the substances listed in Groups I and II of Annex B a full phase-out is foreseen until the year 2000, whereas for Methylchloroform the phase-out is envisaged for the year 2005, with a clause stipulating review of this schedule in 1992.64

Although a tighter schedule could have been imagined, these results are rather satisfactory and orientated towards the proposals made by the Executive Director65. The removal of HCFC's and "other Halons" from the Amendment constitutes a serious flaw, however. HCFC's are used as substitutes for CFC's and still possess roughly 0.2 - 10 percent of their ozone-depleting potential.66 These chemical substances were foreseen to be controlled and reduced in the blueprint for the final negotiations 67 but this proposal was turned down due to persistent pressure from the chemical industry threatening that they were unable to develop any more alternative substances, if HCFC's were to be phased-out.68 As a result the parties 69 only adopted a declaration on "transitional substances", expressing their will

63 See the Report, UNEP/Ozl. Pro. 2/3, p. 27 et seq.

64 Art. 2 E para.5, ibid.

65 Cf. the Note by the Exe. Dir., UNEP/Ozl. Pro. Wg. IV/2, 15 May 1990, p. 3; it actually goes further, since the proposal provides only for a 50 percent reduction of Methylchloroform in the year 2000, see ibid.; this seems to be caused by a decision of the US Congress to ban this substance in the year 2000, Friends of the Earth Intemational (FOEI), The New Montreal Protocol, August 1990.

66 Cf. FEA 1989, note 6, p. 34 et seq.

67 The Report of the Legal Drafting Group, see UNEP/Ozl. Pro. WG.II/(1)/3, p. 12 of Annex II.

68 Cf. The Independent, 22 June 1990, "Du Pont plans CFC-altemative plants"; cf. also FOEI, note 65.

69 And non-parties present at the conference. 
to limit the use of HCFC's and to destroy them at the end of their final use. ${ }^{70}$ Despite this apparent backlash the resolution may yet create enough uncertainty for industry to deter them from developing and applying these substances extensively. A similar criticism can be levelled against the fact that "other Halons" 71 are included in this resolution only 72 and not - as originally foreseen - covered by the Amendment. 73

\section{bb) The Financial Mechanism}

Already the Vienna Convention 198574 and the Montreal Protocol 198775 recognized the special need of developing countries for financial and technological assistance. The accession of developing countries to these treaties became more and more important after some of them had begun to establish their own CFC-related industry76, which to-date account for only 1 percent of the global CFC-production but grows at a fast rate77. Equally, multinational enterprises had to be barred from transferring their production to non-parties. After it had become apparent that the ozone-depleting substances had to be banned altogether, accession of developing countries to the control measures of the Protocol was recognized as a vital necessity, if the efforts of the industrialized countries were not to be flawed.78

The costs of converging CFC-related industries in developing countries were roughly known due to two studies prepared for UNEP79 and one study conducted by the United States 80 . Additionally, UNEP had beforehand commissioried a study on structural and institutional implications of a financial mechanism. 81 On this last aspect almost all the attention and debate was focused - with surprisingly little bargaining at all over figures. The early estimation of $\$ 160$ - 240 million was not even revised after country-studies had been

70 Annex VII to the Report, UNEP/Ozl. Pro. 2/3, p. 67.

71 These are Halons not listed in Annex A of the original Protocol, Halons which have not been in use yet and whose ozon-depleting potential is not known.

72 Annex VII to the Report, UNEP/Ozl. Pro. 2/3, p. 67.

73 Cf. the Report of the Legal Drafting Group, UNEP/Ozl. Pro. WG.II/(1)/3, p. 6.

74 E.g. Art. 4 para. 2

75 E.g. Art. 5 paras. 2, 3; Art. 9 para. 1; Art. 10 para. 1.

76 Cf. UNEP/Ozl. Pro. WG./II (2)/Inf. 2.

77 Cf. the revised data report, UNEP/Ozl. Pro. 2/2/Add. 4/Rev. 1, p. 7; India was even reported to have sold a whole CFC production plant to Iraq.

78 At the London Meeting the People's Republic of China and India were not parties to the Protocol, but at the end of the conference their delegations announced a recommendation to their govemments to ratify the Protocol in its revised form.

79 Studies by Markandya, UNEP/Ozl. Pro. WG. II (2)/Inf. 2 and Pargal/Kumar, Exe. Sum. in UNEP/ Ozl. Pro. WG. II (2)/4.

80 Printed as UNEP/Ozl. Pro. WG. III (2)/Inf. 1.

81 By Rudolf Schmidt, UNEP/Ozl. Pro. WG. II (2)/Inf. 3. 
presented by China and Egypt. Obviously the sums in question in this case were not considered relevant.

It was another aspect which gave the negotiations their political importance, rendered the meetings very difficult and sometimes even pushed aside the matter in question: The mechanism established by the Amendment is expected by almost everyone to serve as a model for future conventions on environmental issues. 82 It was precisely for this reason that the United States pressed for the insertion of a clause denying any prejudicial effect of the Amendment on further environmental issues. 83 Without having any legal effect, since future negotiations on different issues cannot be prejudiced by a simple treaty, this clause nevertheless bears some political importance and facilitated the US agreement to the mechanism.

According to the new Art. 10 para. 1 of the Montreal Protocol84 the Financial Mechanism will provide financial and technical assistance to those parties of the Protocol, which are operating under para. 1 of Art. 585 to meet the incremental costs incurred through compliance with the control measures of the new Protocol. The term "incremental costs" is not defined, the parties instead agreed on a so-called "indicative list" of these costs. 86 As this list is not exclusive and more types of costs may be added to the list, the overall financial commitment of the contributing parties is not yet known.

The great bulk of the financial flows will be channelled through a Multilateral Fund into which the industrializd states 87 pay the amount needed according to and on the basis of the United Nations scale of assessment for contributions 88 . Up to 20 percent of the annual

82 Like e.g. a Convention on Climate Change, for the Protection of Rainforests etc.

83 Art. 10 para. 10, UNEP/Ozl. Pro. 2/3, p. 34; cf., however, the interim Financial Mechanism, ibid., p. 15, where the same clause appears as Art. 10 (11) due to a new paragraph 8 later introduced.

84 The old Art. 10 is going to be replaced, its provisions for technical assistance will be taken over by an enlarged Art. 5 and a new Art. 10 A, see note 83, pp. 31, 36.

85 These are developing countries with a per capita consumption of less than $0.3 \mathrm{~kg}$ of controlled substances. For reasons of practicability, the tern "developing countries" was agreed by the parties to comprise all states of the Group of 77 plus Albania, China, Mongolia and Namibia, cf. Bunge, FEA 1989, note 6, p. 168.

86 Appendix I of Annex IV to the Report, UNEP/Ozl. Pro. 2/, p. 42; this Annex refers not to the Amendment but to Decision $11 / 8$ on the establishment of an interim financial mechanism (until the Amendment will enter into force). Nevertheless I shall use it here, since there was a general understanding (and they were carefully worded to allow this) that the Appendices to Decision $\amalg / 8$ were not to be changed for the pernanent Financial Mechanism.

87 "Parties not operating under para. 1 of Art. 5".

88 Art. 10 para. 6; the mode of assessment was not decided until the final day. Against an assessment according to the level of consumption of controlled substances the US pushed through the UNscale, because this give its contributions an upper ceiling of 25 percent, whereas according to consumption its contribution would have been around 30 percent. 
contribution of a donor may be paid to a party operating under para. 1 of Art. 5 through bilateral channels and then subtracted from the contribution into the fund. Bilateral funding was a central demand of some of the donor countries, since they will benefit from established relations to the southem hemisphere and will have the possibility to merge this funding with other financial flows. This will in turn prove beneficial to the donors' industry and foreshadowes exactly the kind of dependency feared by developing countries. The agreed 20 percent therefore constitute a compromise proposed by the Executive Director 89 to bridge the gap between the 80 percent demanded by the industrialized states and the 10 percent conceded by the developing countries.

Much of the negotiating time was spent on the administration of the fund, an issue which would deserve a detailed discussion on its own. It must suffice here to sketch the rough outlines in order to indicate the delicate balance which was achieved in the end. Whereas the overall policy of the fund will be decided by the parties 90 at their annual meetings, specific policies, arrangements and the disbursement of resources will be effected by an Executive Committee. According to its Terms of Reference91 this Committee shall consist of 14 members, of whom 7 will be nominated by the donor parties and 7 by the receiving parties.92 Members of the former group include Finland (the first Chairman), the Federal Republic of Germany, the Netherlands, Japan, Canada, the US and the USSR, the latter group includes Brazil, Egypt, Ghana, Jordan, Malaysia, Mexico and Venezuela.93 This composition is likely to change after India and China have joined the Protocol. The informal arrangement of the groups' composition is made possible by the careful wording of paragraph 2, phrase 2 of the Terms of Reference, allowing each group to select its own members. Because of this balanced representation the efficiency of the Committees' word will depend on the good-will of its members, but a domination of it by the donor countries as demanded by the US 94 - was averted by the developing countries. In practice the Executive Committee will have to compete with the institutions of the third level of administration, notably the Intemational Bank for Reconstruction and Development (World Bank). This bank was assigned the task to "assist in administering and managing the programme"95. Since it will carry out the day-to-day work it will factually have an advantage over the Committee, which is expected to meet only twice a year.96 This strong role of the

89 UNEP/Ozl. Pro. WG. IV/CRP.3, p. 1.

90 Art. 10 para. 4, UNEP/Ozl. Pro. 2/, p. 35.

91 Appendix II of Annex II to the Report, UNEP/Ozl. Pro. 2/3, p. 45.

92 Ibid., para. 2.

93 An informal arrangement by these groups themselves.

94 Cf. The Guardian, 26 June 1990, "US row delays ozone deal"; The Sunday Correspondent, 24 June 1990, "Ozone pact in jeopardy".

95 Para. 3 c) of the Terms of Reference for the Interim Multilateral Fund, UNEP/Ozl. Pro. 2/3, p. 50.

96 The minimum, see ibid. 
World Bank met with strong resistance from developing countries ${ }^{97}$ and (originally) UNEP, who favoured a Multilateral Fund under the Executive Director of UNEP.98 In the end, partly prepared by UNEP99, a solution was found in which the World Bank, UNEP and the UNDP will play their distinctive roles as administering agencies. 100 The model as such is a novelty, but it borrows elements from arrangements like the Tropical Forestry Action Plan, the Energy Sector Management Assistance Programme, the Global Programme on AIDS and the International Fund for Agricultural Development.101

\section{cc) Special Situation of Developing Countries}

Transfer of technology was the second most hotly debated issue at the London Meeting. Ever since the independence of most of the former colonies the industrialized world saw itself confronted with a demand constituting a key element of the so-called "New International Economic Order": the demand for unconditional and free transfer of technology and know-how to the developing countries. 102 The formulation favoured by the developing countries at the London Meeting was, therefore, to make "the obligation of the parties operating under para. 1 of Art. 5 to comply with the schedule of the control measures ... subject to the financial assistance as provided by Article ... and the transfer of technologies"103. For the industrialized countries this justification clause was unacceptable. They professed inability to provide the necessary knowledge, since it was intellectual property owned by private industry. 104 This kind of argument did of course not satisfy the developing countries and the head-to-head clash was not eased until the delegations of the UK and China found a wording acceptable to all.105 This compromise was put into to Articles: a new Art. $10 \mathrm{~A}$ and a reformulated Art. 5. The latter now provides that "Developing the

97 Because of the bank's system of weighted voting according to financial contributions, giving the industrialized states a clear say in its decision-making procedure.

98 See Annex II of a study prepared for UNEP, UNEP/Ozl. Pro. WG. IV/5, p. 5.

99 See the Note by the Exe. Dir., UNEP/Ozl. Pro. WG. IV/4.

100 Para. 3 of the Terms of Reference, UNEP/Ozl. Pro. 2/3, p. 50; UNEP will have the function of an informational clearing house.

101 Cf. UNEP/Ozl. Pro. WG. IV/4, p. 5 et seq.

102 Cf. Kamal Hossein (Ed.), Legal Aspects of the New Intemational Economic Order, 1980; esp. $O$. Schachter, Transfer of Technology and Developing Countries, ibid., p. 156 and Yash Ghai, ibid., p. 15; Verloren Van Themaat, The changing structure of intemational economic law, 1981; cf. also Bryde/Kunig/Oppermann (Eds.), Neuordnung der Weltwirtschaft?, Hamburger Herbert Krüger Colloquium, 1986.

103 Annex III to the Report of the Second Session of the Third Meeting of the Open Ended Working Group, UNEP/Ozl. Pro. G.III (2) 3, p. 12.

104 WIPO provided the Working Group with an expert report on the legal implications involved in the complicated matter of intellectual property, cf. WIPO, WO/INF/51, 20 April 1990; for a further discussion of this topic see infra.

105 For the slow evolution see UNEP/Ozl. Pro. WG. IV/7/Rev. 1-5. 
capacity to fulfil the obligations ... to comply with the control measures ... will depend upon ... financial cooperation ... and transfer of technology", whereas Art. $10 \mathrm{~A}$ obliges the industrialized states 106 to ensure that "the best available ... technologies are expediously transferred ... (and) that the transfers ... occur under fair and most favourable conditions"107.

A subtle system of dispute settlement was inserted into paras. 6 and 7 of Art. 5 to replace the justification clause favoured by developing countries: Any party operating under para. 1 of Art. 5 finding itself in difficulties due to inadequate provision of financial and technological assistance may bring this to the Secretariat's notice and the matter will be discussed at the next meeting of the parties. In the span of time between notification and solution of the problem, no steps to enforce compliance with the control measures are going to be taken. This formula may be called "solomonic", since it reconciles the aversion of the industrialized states to link their performance materially to the developing countries' compliance with the Protocol with the fear of the developing countries to enter into quite detailed obligations without having the means to fulfil them.108 At the same time the formula provides for a "cooling-off" period, thus precluding any unilateral action from other states.

\section{dd) Other Changes to the Montreal Protocol}

The Parties to the Montreal Protocol used the occasion of their Meeting to reword Art. 19 on withdrawal, to adjust Art. 4 on trade restrictions to the new substances 109 and to insert a new paragraph into Art. 7 on data reporting 110. This clause will allow the EC to report in imports and exports of controlled substances only between the community and non-EC members. 111 Data on trade within the Community will not be available anymore after the completion of the internal market in 1993.

106 Although the text refers to "each Party"!

107 UNEP/Ozl. Pro. 2/3, p. 36.

108 Cf. the African interpretation of this clause: "... that, unless technology is transferred to the Third .World from the industrial nations, they will not have to stop producing CFC's", African Business, August 1990, p. 46.

109 Without a tightening of the time-schedule, though.

110 UNEP/Ozl. Pro. 2/3, pp. 36, 30, 33.

111 Ibid., Art. 7, para. 4. 


\section{ee) Entry into Force}

Some confusion arose before the Meeting on the procedure for the adoption of the Amendment and the conditions for its entry into force. The first drafts of the Amendment provided for a signature in London and a subsequent ratification.112 The Vienna Convention 1985 governing the adoption of amendments to the Protocol, however, does not cater for any signature of Amendments of Protocols. According to its Art. 9 paras. 3 and 4 these have to be adopted by consensus or by a two-thirds majority. This procedure seems to be beneficial and should not be changed113: In case that an amendment is adopted by a two-thirds majority, a signature would make it visible who was in favour of it and who abstained raising the threshold for the latter to accede. 114

Of legal interest is the question as to how many ratifications are required for the entry into force of the Amendment. The Vienna Convention 1985 stipulates in its Art. 9 para. 5, that any amendment to a protocol shall enter info force after at least two-thirds of the parties to the protocol concerned have ratified, except as may otherwise be provided in such protocol. As the number of Parties to the Protocol before the London Meeting was 57115, the number of ratifications required by the Convention would have been 38. According to Art. 2 of the adopted Amendment, however, it will enter into force on 1 January 1992, if at least 20 instruments have been deposited.116 Since the original Protocol does not provide for any exception, the requirement of only one third of ratifications is clearly not covered by the terms of the Convention. Justification for this procedure can be found in the wording of Art. 41 of the Vienna Convention of the Law of Treaties 1969, allowing for two or more Parties to a multilateral treaty to modify this treaty among themselves, if the treaty does not preclude it. The procedure is, however, not covered by the ratio of Article 41, because the London Amendment is designed to replace the original Protocol for preferably all Parties. 117

112 See Art. 2, 3 of the Draft Amendment, Annex II (Report of the Legal Drafting Group) of UNEP/ Ozl. Pro. WG. III (1)/3, p. 27.

113 Although a signature is of course much more impressive in terms of publicity!

114 The procedure would not be prolonged, however, since the present system does not require a signature and there is a number of states who have only ratified Convention and Protocol, cf. UNEP/Ozl. Pro. WG. II (2)/Inf. 4.

11556 states plus the EC, see the Note of the Exe. Dir., UNEP/Ozl. Pro. WG. IV/3, p. 2.

116 See UNEP/Ozl. Pro. 2/, p. 39.

117 The Parties to the Montreal Protocol adopted a decision recommending a revision of Art. 9 of the Convention, Dec. II/16, UNEP/Ozl. Pro. 2/, p. 17; for a further discussion see infra, 6.2. 


\section{c) Other Decisions Adopted at the London Meeting}

Twenty decisions all in all have been adopted by the Parties to the Montreal Protocol at their London Meeting, most of these designed to keep the work going until the next Meeting. Apart from that the Parties adopted, on an interim basis, the procedures and institutional mechanisms for determining non-compliance with the provisions of the Protocol and for Parties found to be in non-compliance. 118 They are the result of lengthy discussions within the Ad hoc Working Group 119 and represent the smallest common denominator. It has been carefully avoided to establish any judicial or quasi-judicial procedure or to make it confrontational. The major obstacle to a more elaborated procedure seems to have been the same that impeded the negotiations on the Montreal Protocol itself: the anxiety of the Parties not to set a precedent in the field of environmental law.120

The most important decision adopted at the London Meeting was undoubtedly to establish on an interim basis "for a three-year period from 1 January 1991 to 31 December 1993 or until such time as the Financial Mechanism is established" the Financial Mechanism dealt with above. The necessity to establish such a mechanism provisionally was realized very early by UNEP's Executive Director. 121 One of the reasons is singled out quite easily as the need to bring about the accession of more developing countries as soon as possible. A second reason may best be described as the creation of facts. The creation of facts, first of all to use the favourable mood of the hour and secondly to circumvent ratification procedures by the Parties' legislative bodies.

Somewhat problematic, however, is the legal base of that decision establishing the interim Financial Mechanism. 122 Throughout the Meeting this point was never of ficially raised. No guidance can be found in the documents, since the decisions do not refer to their legal base. A search through the Convention and the Protocol will reveal, that no express provision to adopt such a decision exists in either of these. The only provision in the Protocol wide enough to allow for extensive interpretation 123 is Article 11 (4) (j), according to which the functions of the meetings of the Parties shall be to "consider and undertake any additional action that may be required for the achievement of the purposes of this Protocol". Read

118 Annex III to the Report, UNEP/Ozl. Pro. 2/3.

119 Cf. its Report, UNEP/Ozl. Pro. LG. 1/3, 14 July 1989.

120 Cf. the statement of the working groups' chaiman, Mr. Patrick Szell, UNEP/Ozl. Pro. LG. 1/3, p. 2.

121 Cf. his proposal of 28 May 1990, UNEP/Ozl. Pro. WG. IV/6.

122 Another legal problem may arise intemally for some parties with respect to their national budgets, because the original Protocol did not contain any financial commitment of this size.

123 It would be difficult to rely on the concept of implied powers here, which was conceived for international organizations, cf. Manfred Zuleeg, Implied Powers, in: R. Bernhardt (Ed.), Encyclopedia of Public Intemational Law (EPIL) 7 (1984), p. 312. 
together with Article 5 (3) of the Protocol ${ }^{124}$ and taking into account the urgency of the problem this wording may well cover the establishment of the mechanism. Some doubts do remain, because Art. 11 (4) (j) allows for decisions to be adopted by a simple majority. Article 40 of the Rules of Procedure, on the other hand, requires for substantial decisions a two-third majority and the original financial provisions in the Protocol even require an adoption by consensus. 125 As the decision establishing the mechanism was adopted by consensus this condition was met and, in any case, no Party objected to the procedure in plenary.

These inconsistencies nevertheless serve very well to illustrate the sense of urgency that prevailed at the London Meeting.

\section{Assessment and Comments: New Tendencies in International Law and Relations}

The negotiations on the London Amendment and the results of the Meeting invite some comments.

1. From an international lawyers' perspective the adoption of the London Amendment contributes to the shift of international law from the traditional law of coexistence to a law of cooperation. Traditionally, intemational law was concemed with the rights and obligations of sovereign states, defining areas of exclusively jurisdiction and regulating the competition of these states for natural resources. 126 States are in principle free to act without any outside restraints on their territory, and to exploit and use their natural resources according to their political will.127 This system of norms does reflect the situation of the post-war international society, where there was only one global threat - military annihilation - which could be handled with the traditional law of coexistence. Changes in a society's condition and environment do require new behaviour, however, and new instruments to tackle problems which did not exist before.

One of the fundamental changes that have occurred in the last decades is the threat to the very basis of human life on earth. 128 Deterioration of the natural environment on a global

124 Requiring the Parties "to facilitate ... the provision of subsidies, aid, credits ...".

125 Cf. Art. 11 (3) (b) and 13 (2) conceming financial rules.

126 Cf. W. Friedman, The Changing Structure of Intemational Law, 1964, p. 60 et seq.

127 A "laissez faire" approach, cf. also Randelzhofer/Sinma, Das Kemkraftwerk an der Grenze, in: Festschrift für Berber 1973, p. 389.

128 This threat has been referred to as "global security threat" in order to emphasize its importance and to transfer the issue into the realm of "high politics", cf. Environmental Problems: A Global Security Threat, Report of the Twenty-fourth United Nations of the Next Decade Conference, The Stanley Foundation 1989. 
scale cannot be tackled on a national, bilateral or regional level but requires worldwide concerted efforts. 129 This is a situation to which traditional international law is not adapted, mainly because it does not provide adequate systems for cooperation and concerted action. Since intemational law is not a centralized, hierarchical system with a legislating body, changes will require the political will and interaction of all international actors. 130 Hence, its development will be of a piecemeal character. Concentrated on some of the most urgent issues, "vertical" systems of regulation might lead to "sectoral world orders"131, which will slowly evolve into a new kind of international legal order. As this change is of an evolutionary character, the mechanisms of present international law will be used to bring it about. The Ozone Layer Regime does provide a formidable opportunity to witness the evolution of one of these sectoral orders. 132

2. The system established for the protection of the ozone layer is designed to cure one of the much deplored structural and institutional deficiencies of the international legal system. 133 Instead of creating new, costly and bureaucratic intemational organizations, the Parties devised a complex system of regulations, administrative procedures and dispute settlement which seems to be stable enough to provide a framework for continuous activities but flexible enough to be swiftly adapted to changed circumstances. Ultimate decisionmaking power rests with the Parties to be exercized at their annual meetings where the entire Convention or Protocol is open for revision. These meetings do not only constitute the legislative body134 but also the highest administrative decision-making135 and quasi-

129 The result of two major reports: The Global 2000 Report to the President - Entering the Twentyfirst Century, 1980 and the Report of the World Commission on Environment and Development (Brundtland-Report), Our Common Future, 1987.

130 The absence of so-called "formal" sources of law, cf. Ian Brownlie, Principles of Public International Law, 4th ed., p. 1 et seq.; cf. also Sir Robert Jennings, Intemational Law, in: EPIL 7 (1984), p. 278.

131 Cf. M. Kilian, Umweltschutz durch Intemationale Organisationen, 1987, p. 396 et seq.; for the expression cf. Graf Vitzthum, The Search for Sectoral World Orders, in: Vitzthum (Ed.), Aspekte der Seerechtsentwicklung, 1980, p. 273.

132 Another example: the Air Pollution Regime in the framework of the ECE, cf. the Convention on Long-Range Transboundary Air Pollution, 13 Nov. 1979; reprinted in 18 ILM 1442 (1979); for an extensive discussion see Flintermann/Kwiatkowska/Lammers, note 5; cf. also Amy A Fraenkel, The Convention on Long-Range Transboundary Air Pollution: Meeting the Challenge of Intemational Cooperation, 30 Harvard Intemational Law Joumal (1989), p. 447.

133 Cf. e.g. I. Claude, Swords into Plowshares. The Problems and Process of Intemational Organization, 4th. ed., 1977, p. 83 et seq.; Eugene B. Skolnikoff, Technology and Intemational Relations: A View Back and Ahead, in: Davidson/Cetron/Goldhar (Eds.), Technology Transfer, 1974, p. 443; for a legal analysis of institutional Problems cf. D. W. Bowett, The Law of Intemational Institutions, 3rd ed., 1975, p. 299 et seq.

134 Cf. Art. 11 (4) (h), (i), (j).

135 Cf. Art. 11 (4) (a), (b), (g) and the Terms of Reference forthe new Executive Committee, supra 5. b) bb). 
judicial authority ${ }^{136}$. This dynamic structure developed for global environmental protection appears to be able to cope with the problems posed, especially when comparing the quick development since 1985 to the glacial standards of ordinary international diplomacy.

Nevertheless the present procedures for the revision of the Montreal Protocol will themselves require some revision, lest the adoption of more amendments will lead to considerable confusion. After the ratification of three or more amendments by very differently composed groups of parties, the rights and obligations of individual Parties towards others will be very difficult to determine. 137 It would be advisable, therefore, not to change Article 9 of the Vienna Convention 1985 so as to lower the threshold for the entry into force 138, but to make the ratification by a two-thirds majority - representing a majority of developing countries and a ma jority of industrialized states - binding upon dissenting states.

3. It has become clear that the issues of economic development and preservation of the global environment are inextricably linked.139 Not only is poverty in developing countries one of the main reasons for global environmental deterioration 140 , but the very cure which has been prescribed may have devastating effects. The ecological crisis is about to thwart any plan to solve the North-South conflict by simply improving the South's economic performance. 141 Worldwide interdependence 142 on the "spaceship earth"143 requires a concerted effort by all states to foster a different kind of development in the North and the South to prevent ecological and economical desasters. 144 This is a genuine interest of the industrialized states and in order to stress its reciprocal character145 the establishment of the Financial Mechanism has been called a "deal" between the two hemispheres. 146 The

136 Cf. Art. 11 of the Vienna Convention 1985, applicable according to its paragraph 6.

137 Some confusion arose already in plenary at the London Meeting with regard to the precise sets of rules that would govem the relation of certain parties.

138 Cf. supra, 5. b) ee).

139 This has been best expressed by the World Commission on Environment and Development (WCED) (Brundtland Commission), Our Common Future, 1987.

140 E.g. because forests have to be used as an energy source by the poor leading to desertification, and because natural resources are in general overexploited in order to finance interest and debt payments.

141 Brun-Otto Bryde, Von der Notwendigkeit einer neuen Weltwirtschaftsordnung, in: Bryde/Kunig/ Oppermann (Eds.), Neuordnung der Weltwirtschaft, 1986, p. 31.

142 Cf. Zemanek, Interdependence, EPIL 7 (1984), p. 275; for a view from the Third World cf. S.P. Varma, "Interdependence": The Third World Perspectives, in: Misra/Smith Beal, Intemational Relations Theory. Westem and Non-Westem Perspectives, New Delhi 1980.

143 Quite a good picture with a fundamental flaw: in contrast to a spaceship the earth is a more "closed system", without an outlet for example to get rid of hazardous waste.

144 Cf. the Report of the WCED, Our Common Future, 1987, p. 46.

145 For the concept of reciprocity cf. Bruno Simma, Reciprocity, in: EPIL 7 (1984), p. 400.

146 It is thus not quite understandable that some Westem diplomats spoke of "political blackmail" by the developing countries: these states simply used their new bargaining power as equal partners (a 
mechanism established by the Parties to the Montreal Protocol does set a hopeful precedent and may point to a "non-zero-sum"-strategy of all international actors involved. 147

4. Technology transfer will be one of the main issues in the establishment of increased cooperation. Having always been a highly political issue 148 , especially after decolonization in the 60 s and $70 \mathrm{~s}^{149}$, this demand of developing countries will in the next decade become an imperative. They cannot be expected to accept dependency on the former colonial powers and their industries. 150 If developed countries seriously want to prevent ecological desasters, they will have to assist developing countries not only by providing money, but by providing sustainable technology and know-how.151 A second reason, however, is the growing dependency of all states, north and south, on the provision of technology and know-how which is possessed exclusively by transnational corporations. Throughout the negotiations on the London Amendment these companies were able to exert considerable pressure on the delegations. 152 In order to avoid a compulsory licensing system alien to our economic system govemments should retain some scientific potential to conduct independent research. This would allow them to set criteria for research, to react swiftly, and to share knowledge with less developed countries. It might even be advisable to revive the idea of establishing international research centres, where research is conducted in areas and on subjects according to intemational needs. 153 The disappearance of the East-West military conflict and the subsequent drastic reduction of military forces and equipment should release enough financial and scientific resources to establish these research centres just in time.

phenomenon to which these delegates may not be accustomed!); for a similar misperception see Konrad Adam, Frankfurter Allgemeine Zeitung, 15 August 1990.

147 A terms used in "Game Theory" to characterize a situation in which the gain of one actor is not necessarily the loss of another and vice versa, but where by cooperation the actors may increase the overall gain, cf. Plano/Riggs/Robin, The Dictionary of Political Analysis, 2nd. ed., 1982, p. 58; $M$. A. Kaplan (Ed.), New Approaches to Intemational Relations, 1968, p. 486; Zinnes/Gillespie, Mathematical Models in Intemational Relations, 1976, p. 376.

148 Cf. e.g. Henry R. Nau, Technology Transfer and U.S. Foreign Policy, 1976.

149 Cf. the literature note 102.

150 This is especially true for India, as its delegate Maneka Gandhi has made abundantly clear at the London Meeting.

151 In this context the expression "sustainable" should be underlined, since it is not in the interest of the worlds community and the environment to fumish developing countries with outdated technology. The same holds true for the provision with substitutes which will have to be replaced in the near future due to their inherent danger, e.g. to the global climate.

152 When a transfer of technology was discussed and when substitutes for CFC's were removed from the Amendment, cf. supra 5. b) aa).

153 Cf. Eugene B. Skolnikoff, Technology and Intemational Relations: A View Back and Ahead, in: Davidson/Cetron/Goldhar (Eds.), Technology Transfer, 1974, pp. 443, 461. 


\section{Conclusions}

The assessment of the control measures for ozone depleting substances agreed on in London necessarily has to be ambivalent. Whereas the decision to phase out these substances completely is certainly a major step forward in the protection of the ozone layer, this result is diluted by the rather slow time-scale for the phase-out, the possibility to retain $15 \%$ of the production in order to satisfy the basic domestic needs of developing countries and by the exclusion of some already identified ozone-depleting substances from the Amendment.154 At the Meeting it was quite evident that no-one expects these control measures to survive the 1992-meeting of the Parties.

The decision, however, to create an unprecedented "Financial Mechanism", thereby breaking up the traditional trias of govemmental flows to developing countries 155 , will secure this Meeting a footnote in intemational legal history.

154 Prof. Farman went so far as to call the result of the London Meeting a "deception".

155 Official Development Assistance (ODA), nonconcessional official flows from Multilateral Development Banks and export credits and guarantees, cf. Development Committee of the World Bank and the IMF: The Adequacy of Resource Flows to Developing Countries, 1988, p. 10. 
human rights communications and the relationship of the right of petition or communication in the inter-American system with other human rights petitioning systems.

As the first question, the local remedies rule has been applied with flexibility in the interAmerican system pursuant to its rationale in the domain of international human rights protection, endowed with a specificity of its own. By means of procedural techniques in a diversity of solutions, presumptions have been made to operate in favour of the alleged victims. Without detracting from generally recognized rules of international law, the local remedies rule has received a particularly flexible application in the inter-American system of human rights protection (contrasting, e.g., with its more rigid application in discretionary diplomatic protection), disclosing the interaction between international law and domestic law and stressing the importance of the element of local redress in the international legal procedure.

As to the second question, there was been an evolution from the initial absence of a clause of co-ordination between petitioning systems to the provision of express indications or guidelines to achieve that co-ordination, without detriment to the complainants and to the necessities of protection. This has contributed to the enhancement of the procedural position of the alleged victims. It is important and necessary that techniques and presumptions keep on being applied in a way to redress the balance in favour of the alleged victims, pursuant to the ultimate object and purpose of human rights instruments, which are fundamentally victim-oriented.

The New Montreal Protocol: A Small Step for the Protection of the Ozone Layer, a Big Step for International Law and Relations

\section{By Hermann Ott}

In June, 1990, the parties to the Montreal Protocol on Substances that Deplete the Ozone Layer met in London to negotiate and adopt an amendment which is remarkable in many ways and may very well open a new chapter in international relations. It was agreed upon to phase out completely the production and consumption of a whole range of chemical substances which are known to destroy the ozone layer. In addition, the parties reached an unprecedented agreement on a financial mechanism with as of yet unforseeable consequences for North-South relations, for the international economic order and for international law. This financial mechanism will be funded by the industrialized states and is designed to enable developing countries to restructure their industries in order to avoid ozone-depleting substances. Thus the conference may have set an important precedent in the fight against global environmental deterioration and may prove to be a step towards a genuinely sustainable development. 
The article focusses on three main aspects: Firstly, the author gives a brief account on the scientific background necessary to understand the scope of the problem and some examples of the national and international legislative reactions. The second part deals with the decisions taken at the London Meeting and with the changes to the Montreal Protocol. Finally, the results are considered with respect to their possible medium and long term implications.

\section{The State-Religion Amendment to the Constitution of Bangladesh: A Critique}

\section{By Shah Alam}

In 1988, the parliament of Bangladesh passed the Eighth Constitutional Amendment Act introducing Islam as the state religion. This act put an end to the constitutionally guaranteed equality between Muslims and Hindus, Christians and Buddhists. The implications of this constitutional amendment reach far, as it stands in contradiction to the consciousness and the ideals of the struggle for independence, which have been included in the 1972 constitution of Bangladesh. As the amendment collides with fundamental rights of the citizens still guaranteed by the constitution, there is sufficient ground for questioning the legality of the act underlying this change.

The basis for examining the constitutionality of the Eighth Amendment to the Constitution of Bangladesh regarding the declaration of Islam as the state religion is formed by a historical and socio-political evaluation of the issues involved. Legal questions are tested on the touchstone of relevant historical facts and socio-political reality. The author comes to the conclusion that the proclamation of Islam as the state religion is in contradiction to the spirit of the liberation war which formed the foundation of both independence and the constitution. He contends that a mere act of parliament is sufficient to change the provisions of the constitution that embody the ideals of the struggle for independence. Any amendment involving change in the basic features of the constitution can only be effected by referring it to the people, i.e. by way of referendum. This mandatory requirement for amendment which is set forth in Art. 142 (1 A) of the constitution was not adhered to in the case of the impugned Eighth Amendment and it is, hence, ultra vires and invalid. 